\title{
Management of educational resources development in improving the quality of education in elementary school
}

\author{
Jhon Hendri ${ }^{1}$, Edi Harapan ${ }^{2}$, Dessy Wardiah ${ }^{3}$ \\ ${ }^{1}$ SD Negeri 14 Air Kumbang \\ ${ }^{2}$ Universitas PGRI Palembang
}

\begin{tabular}{l} 
Article Info \\
\hline Article history: \\
Received Jul $13^{\text {th }}, 2021$ \\
Revised Aug $11^{\text {th }}, 2021$ \\
Accepted Aug $30^{\text {th }}, 2021$ \\
\hline
\end{tabular}

\section{Keyword:}

Management

Quality

Education

\begin{abstract}
This study aims to identify and describe the management of educational resource development in improving the quality of education at the 14 Air Kumbang State Elementary School. With a qualitative descriptive research method, the use of qualitative descriptive research design in this study is intended to describe and analyze the management of educational resource development in improving the quality of education at 14 Air Kumbang State Elementary Schools. The technique of collecting data in this research is through interviews, observation, documentation and triangulation. The results showed that the steps for implementing human resource development management were planning, organizing, actuating, and controlling. The obstacles faced in the implementation of human resource development in improving the quality of education at the Air Kumbang 14 Public Elementary School are: lack of teacher consistency (in absenteeism, seriousness in training). The effect of these constraints in the implementation of training is that the results obtained are not optimal, the results are not in accordance with what is expected and can reduce the RABM and in training are also limited by funds
\end{abstract}

(C) 2021 The Authors. Published by IICET.

This is an open access article under the CC BY-NC-SA license

(https://creativecommons.org/licenses/by-nc-sa/4.0

\section{Corresponding Author:}

Jhon Hendri

SD Negeri 14 Air Kumbang

Email: hendrijhon31@gmail.com

\section{Introduction}

The management of educational resource development in the current reform era is one form of implementation of Law Number 20 of 2003 concerning the National Education System, which provides directions for management of the education system in Indonesia, particularly for the management of early childhood education units, basic education and middle school uses the principle of minimum service standards and is supported by school-based management.

The Indonesian education program is implemented in the development of the five pillars of education, namely increasing the availability of education services, increasing the affordability of education services, increasing the quality or quality and relevance of education services, increase equality in obtaining educational services and increase the certainty or security in obtaining educational services. In essence, the five pillars are interrelated with each other, but the aspect of education quality assurance is a fairly dominant factor or pillar in education management activities. 
The quality of National Education will be measured through the achievement of all National Education Standards, including content standards, processes, competence for graduation, educators and education personnel, facilities and infrastructure, management, financing and education assessment. The serious and sincere attention of the parties to the efforts to fulfill and realize all these standards will determine the quality / quality of education.

Human resource management in education in order to improve the quality of education is very important. This is because in an educational organization or institution, it can progress and develop with the support of human resources in the field of education. Therefore, any educational institution or organization that wants to develop must pay attention to human resources and manage them well, in order to create high quality education.

This is because the policy of increasing the quality of education that is high if it is addressed consistently will produce competent graduates, which in turn will be able to produce competitive citizens in large numbers. Educational programs to improve the quality of human resources are very important because there are many problems in government institutions, social institutions and various activities in society whose effectiveness depends on the quality of human resources, both in intellectual capacity and moral integrity in their responsibilities to society.

[1] human resources are one of the key factors towards prosperity. Creating quality human resources with skills and high competitiveness is a demand for development towards prosperity. The low quality of education so far has been strongly influenced by several components according to [2], including: the quality of teachers, administrative staff and learning infrastructure such as textbooks, learning media, learning resources, equipment / support, inadequate learning laboratories.

The government is required to create and optimize human resources in various fields according to their needs. The analysis of this research is based on the theory of human resource empowerment in accordance with the need to improve the quality of education towards the creation of superior and competitive human resources starting from improving the quality of the performance of professional educators.

[3] Empowerment contains two definitions, namely: to give power to give power, to transfer power, to delegate authority to other parties, to give ability to. This meaning implies that the concept of improving the quality of education has not yet optimized the empowerment of teacher performance, which has a role in improving the quality of education.

The development of the quality of teaching staff is a manifestation of capacity building with nuances of empowering the human resources of teaching personnel through the development of various abilities and responsibilities as well as a synergistic atmosphere between the government and teachers. The continuous effort to optimize teacher performance is an important factor compared to other factors in improving the quality of education. This has been realized and carried out by the government through the assignment of further studies, various training and upgrading of teachers.

The main key for optimal planning and educational development programs in schools is in the hands of educators and education personnel in schools. Thus it is clear that the problem of increasing workforce professionalism is very important to pay attention to. In this regard, in detail, it has been stated in PP 19 of 2005 article 28 and article 29 regarding academic qualifications and competencies that must be met as educators for children with special needs. Competencies that must be met include 4 competencies, namely: a. Pedagogic competence; b. Personality competence; c. Professional competence; and D. Social Competence. More detailed provisions are outlined in Permendiknas No. 16 of 2007 concerning Academic Qualifications and Teacher Competencies.

Efforts to improve the quality of education have begun to be made by the government through several efforts, such as the teacher and lecturer certification program, which demands that at least teachers qualify for S1 and D4, while lecturers at least qualify for S2 or S3. They must also have competence in scientific, didactic, communication with students and personalities. Several reforms of school buildings, curriculum updates that emphasize students and students actively learning to achieve certain minimum standards, education standardization and others have been carried out by the government.

Seeing the importance of resources in the context of the education system, human resource management must be carried out properly. Human resource development in an organization including schools, is not just the procurement of human resources, but integrated action and various functions ranging from planning, staffing or recruitment, appraisal and coaching and human resource development. 
Management of educational resources, in this case focused on the management of the development of human education resource management in order to improve the quality of education, is very important. This is because in an organization or educational institution, it can progress and develop with the support of human resources. Therefore, any educational institution or organization that wants to develop must pay attention to human resources and manage them well, in order to create quality education.

[4] Based on research conducted it is explained that the Indonesian nation is faced with a dramatic phenomenon, namely low competitiveness as an indicator that education has not yet fully produced quality human resources. This is a challenge so that all components of education stakeholders can further improve their performance. Efforts to create a good education system as a vehicle for realizing educational goals can be done by updating the vision, mission and national education strategy and implementing it in the field. All of that is needed by holding capacity building in all aspects of life towards sustainable good governance.

In this case the success of education cannot be separated from several supporting factors. The supporting factors are educators, who are being educated, learning materials, learning methods, objectives and the last factor is environmental factors. Some of these factors are the success of education that is wrapped in an educational institution called a school. School is a place for channeling education to students by educators who are considered capable of transmitting all knowledge.

From the results of preliminary observations at 14 Air Kumbang State Elementary School, it was found that the human resources at the elementary school were not optimal, because SD Negeri 14 Air Kumbang was a remote school category. There are still several conditions in the field that actually do not meet accreditation standards, such as teacher education, only 4 teachers with an undergraduate education, 1 person graduated from high school and 2 people graduated from MA. And the supervision of the principal is not carried out continuously, so that after completing the process of accreditation of education culture and education personnel, they return to habits that do not pay attention to administration and Standard Operating Procedures in all learning activities,

By looking at the issue issues as stated above, the main problems can be formulated which will be the focus of discussion in this study, namely the Management of Educational Resources Development in Improving the Quality of Education in 14 Air Kumbang Public Elementary Schools.

Human resource management is a series of organizational activities directed at attracting, developing, and maintaining an effective workforce, the same thing was explained [5] that human resource management is defined as the utilization of human resources within the organization which is carried out through resource planning functions. human resources, human resource planning, recruitment and completion, human resource development, career planning and development, compensation and welfare. [6] explained that human resource management is a series of human resource management activities that focus on practices and policies, as well as management functions to achieve organizational goals.

Human resources are resources that have a special position compared to other sources. Human resources are able to survive because they have managerial competence, namely the ability to formulate a vision and strategy as well as the ability to acquire and mobilize other resources in order to realize the vision and implement change strategies. Thus the element of human resources is the only element in an organization that has dynamics to develop when obtaining knowledge and development from its environment.

The term Human Resources is often shortened to "HR" in English terms human resource. The word human in Indonesian means human or human. [7] "resource" means a source of resources / strength, so human resources are defined as sources of power that come from humans that can be utilized by the organization.

Quality is something related to passion and self-esteem. For every institution, quality is the main agenda and improving quality is the most important task. However, there are some people who think of quality as a concept that is full of puzzles. Quality is seen as confusing and difficult to measure. Quality in the view of people sometimes contradicts the quality in the view of others, so it is not bad if there are two experts who do not have the same conclusion about how to create a good institution.

[8] That the term quality of education is an inseparable part of the purpose of education itself. So that the resulting quality of an institution will be measured from the output of an institution. A reflective study of historical experience shows that educational orientation has undergone fundamental changes from time to time. So that the quality of education itself is delimatic and not in accordance with the expected character direction. 
The quality of education is determined by the level of success of all the factors involved in achieving educational goals. Quality of education is education that is useful and can meet the needs of society and its environment in relation to cultural development groups and prepare people to accept changes and technological developments. [9], he explained that the quality of education is the output that is maximally processed by educational institutions. Quality in education is emphasized on students and the processes in them.

[10] explained that the quality of education is an indicator to see productivity and is closely related to management or management issues in institutions or schools.

\section{Method}

This study uses qualitative research methods, as [11] that qualitative research is a research method based on the philosophy of positivism, used to examine the conditions of natural objects, where the researcher is the key instrument, the data collection technique is done by triangulation, the data analysis is inductive / qualitative. , and qualitative research results emphasize meaning rather than generalization [12] explained that qualitative research is research that does not start from a previously prepared theory, but starts from the field based on the natural environment.

Researchers use qualitative research to make it easier for researchers to determine problem formulation and report preparation. Furthermore, the descriptive method was chosen because the data sought, namely from the form of words. In addition, the descriptive method was chosen to make it easier for researchers to collect data and to describe the data obtained from the field in the form of data in the form of descriptions. Qualitative research requires that the understanding and interpretation results obtained are compared and agreed upon by humans who are used as data sources.

There are several reasons for using qualitative methods. One of them is that this method has been used widely and can cover more aspects than other methods of investigation. This method contributes a lot to science by providing up-to-date information, and can help us identify factors that are useful for conducting experiments. Furthermore, this method can be used to produce a situation that may exist in certain situations.Another reason why this method is used so widely is that the data collected is considered very useful in helping us to solve ourselves, or to solve problems that arise in everyday life.

The research location used as a data source is at the 14 Air Kumbang State Elementary School, which is located in Padang Rejo Village, Air Kumbang District, Banyuasin Regency. The research period starts from September to completion.Sources of data in research are the subjects from which data can be obtained. Data collected from interviews, field observation notes, portraits, individual documents and official documents. Sources of data in this study use primary data sources and secondary data sources. Primary data sources are data sources that directly provide data to data collectors. The primary data sources are from the first informants, namely the principal, teachers, students and administration. Secondary Data Sources are records of events or records that are far from the original source. For example, the decision of a meeting of an association is not based on the decision of the meeting itself, but from news sources, newspapers, news about the newspaper, including secondary data.The data validity process was carried out to provide an overview of the truth of the data found by researchers in the field. [11] states that the validity test in qualitative research includes testing data credibility (internal validity), transferability (external validity), defense (reliability), and confirmability (objectivity). In this study, in accordance with the character of qualitative research, it will use interactive data analysis with the Miles \& Huberman model by taking the following steps (1) data reduction, (2) data presentation / data presentation, (3) drawing conclusions and then being verified [13].

\section{Results and Discussions}

From the results of research on the implementation of For the management of human resource development, it will be carried out from the training planning, what is done by the Air Kumbang 14 State Elementary School is to see and observe the mission and objectives of the school. The institution has a clear mission and objectives and serves as a guideline for the educator training program. The planning of training for teachers at SD Negeri 14 Air Kumbang was also supported by the results of observations made by researchers on November 6-7, 2020, that the school held a workshop to determine the vision, mission and goals of the school.

Mission as a determination of training needs, that training is held according to current or future needs, such as: training for educators to improve professionalism and quality of learning in the classroom and training to establish cooperation between educators in the context of school development and progress, there are also 
training or workshops and seminars. This is supported by observations made by researchers on November 6-7, 2020, namely that the principal facilitates teachers to take part in training, workshops, and seminars, both at school and outside of school held by related agencies. The following supports the results of interviews and observations:

[14] research entitled "Human Resource Management in Improving the Quality of Education at SMP IT Sumpit". Human resource management is a form of effort to improve quality in the development of an educational institution. Improving the quality of human resources requires a mechanism that is able to regulate and optimize the various components of human resources in schools, including educators and education personnel. The purpose of this study is to determine the natural background of SMPIT, the implementation of human resource management in improving the quality of education based on planning, organizing, directing, controlling, procurement, development, compensation, integration, maintenance, discipline, dismissal, educational quality, obstacles faced and effort. This research uses descriptive qualitative method. Human resource management from aspects; planning based on the scale of need, organizing involving the organization's management, directing the predetermined job descriptions, quality assurancebased control, increasing the teaching force through trainings. The quality of education uses process standards to achieve competency standards for graduates. The similarity of this research with the preliminary study is that both study about educational resources, while the difference lies in the focus of the research used, for the previous research it was located in the research place, namely in junior high school while for the current research it was in elementary school.

The strategy or method used by the State Elementary School 14 Air Kumbang in determining training to achieve its objectives is based on job analysis or job description. The results of the job analysis can provide an overview of the tasks carried out in the position concerned. The implementation of the program as explained by the Principal of SD Negeri 14 Air Kumbang is very situational in nature. This means that in the implementation of the training program, there is more emphasis on calculating the interests of the institution and the needs of the teachers by considering the cost savings, materials and facilities available.

The location for the training at the Air Kumbang 14 Public Elementary School is adjusted to the needs of the training. Such as the content of the training program, training materials and costs and methods used in training. This means that in the implementation of training can be held inside the school and it can also be held outside the school. This is supported by observations made by researchers on November 6-7, 2020, that one of the strategies of the Head of SD Negeri 14 Air Kumbang to improve teacher performance as one of human resource management in improving the quality of education is to carry out workshops and training for classroom teachers. . For example, a classroom teacher has attended training on the use of Power Points as a learning medium.

Human resource development is divided into two programs, namely training and development. Training and development programs are a series of activities designed to increase the knowledge, abilities, attitudes and performance of individuals, groups, or the entire organization. These activities teach new skills, teach existing skills, and influence teacher attitudes. Training activities are designed to improve skills in current jobs.

The budget or the cost of the training program at the 14 Air Kumbang State Elementary School as explained by the School Principal, that the training costs for educators are borne by the school itself, for that in the implementation of the school program must also look at finances.

\section{Conclusions}

Based on the analysis of research data on human resource development management in improving the quality of education in 14 SDN Air Kumbang and as described in the previous chapter, it can be concluded that human resource development management in improving the quality of education. SD Negeri 14 Air Kumbang has realized four management functions, namelyplanning, which includes the mission and objectives of policies, procedures and rules in developing an organization that will regulate the responsibilities of each level of management involved in the institution, the driving force, in training by giving awards to trainees who show achievement and punishment in accordance with predetermined criteria, namely abilities and abilities and see the changes firsthand after attending the training. In its implementation, what looks more prominent or more interesting is the motivation given by the principal to the training participants, either in the form of money, goods or positions. In addition, the follow-up of training participants after attending the training is required to be able to produce products / results / changes, both in improving the quality of work as educators and changing behavior, as well as the follow-ups that are taken. directly by the Principal who is assisted by the School Representative and the class coordinator, so that the results obtained are in accordance with the school objectives. 
Schools as managers have a deeper role in developing human resources in improving the quality of education. Its existence in schools is very important because human resources have an important role in the process of improving the quality of education in schools and building the nation's next generation, therefore it really needs to be improved through human resource development.

\section{References}

Damanhuri, (2014). Sumber Daya Manusia dan Aplikasinya. Jakarta: Bumi Aksara.

Zamroni. (2012). Meningkatkan Mutu Sekolah, Teori, Strategi dan Prosedur. Jakarta: PSAP Muhammadiyah Rivai, Veithzal \& Murni, S. (2010). Education Management: Analisis Teori dan Praktik. Jakarta: Rajawali Pers Afandi, P. (2018). Manajemen Sumber Daya Manusia (Teori, Konsep dan Indikator). Riau: Zanafa Publishing.

Yuniarsih, Tjutju \& Suwatno. (2011). Manajemen Sumber Daya Manusia (Teori, Aplikasi, dan Isu penelitian). Bandung: Alfabeta

Marwansyah. (2016). Manajemen Sumber Daya Manusia. Bandung: Alfabeta

Ruky, A. (2014). Menjadi Eksekutif Manajemen SDM Profesional. Yogyakarta: Andi

Djohar. (2013). Pendidikan Strategik: Alternatif untuk Pendidikan Masa Depan. Yogyakarta: LESFI

Zahroh, A. (2014). Total Quality Management (Teori \& Praktik Manajemen untuk Mendongkrak Mutu Pendidikan). Yogyakarta: Ar-Ruzz Media.

Rohiat. (2018). Kecerdasan Emosional Kepemimpinan Kepala Sekolah. Bandung: Refika Aditama

Sugiyono. (2016). Metode Penelitian Kuantitatif, Kualitatif dan $R \& D$. Bandung : Alfabeta]

Sudjana, N \& Ibrahim. (2014). Penelitian dan Penilaian Pendidikan. Bandung : Sinar Baru Algesindo.

Winarni, EW. (2018). Teori dan Praktik Penelitian Kualitatif Kuantitatif Penelitian Tindakan Kelas (PTK), Reseacrh and Development. Jakarta: Bumi Aksara

Ekawati, F.( 2019). Manajemen Sumber Daya Manusia dalam Meningkatkan Mutu Pendidikan di SMP IT Sumpit. Jurnal ISEMA. 3(2):1-22 